\title{
Rice Sustainability Trend: A bibliometric review
}

\author{
Tendência de sustentabilidade do arroz: Uma revisão bibliométrica \\ Tendencia de sostenibilidad del arroz: Una revisión bibliométrica
}

Received: 05/17/2021 | Reviewed: 05/27/2021 | Accept: 05/31/2021 | Published: 06/14/2021

\author{
Adonir Venuzino Rocha Both \\ ORCID: https://orcid.org/0000-0001-5477-7075 \\ Universidade de Évora, Portugal \\ E-mail: d44601@alunos.uevora.pt \\ Margarida Serra Marques Martins de Moura Saraiva \\ ORCID: https://orcid.org/0000-0001-7256-0769 \\ Universidade de Évora, Portugal \\ E-mail: msaraiva@uevora.pt \\ Manuel Luis Tibério \\ ORCID: https://orcid.org/0000-0001-5489-7368 \\ Universidade de Trás-os-Montes e Alto Douro, Portugal \\ E-mail: mtiberio@utad.pt
}

\begin{abstract}
Sustainability is a topic of interest to science and organizations, an emerging research area in the agrifood field and business management. This area aims to investigate the processes that lead organizations to sustainability and those that lead to organizational learning and the consequent continuous improvement. This work seeks to understand the evolution and trend of studies on the sustainability of the rice value chain. In this sense, a bibliometric review of the literature in the Scopus database was carried out as a methodological procedure, in the years 2001 to 2021 , to observe the publications on the theme of sustainability of the rice value chain existing over the 20 years of this century. Among the results obtained, it was verified that the publications on the topic addressed had an exponential growth from the year 2015, that is, from 80 publications to more than 400 in 2019, and it can be observed that this theme has become of due importance, with a view to sustainability. As an essential result of this study, it is observed that in 2019 there were more than 200 publications on the theme of rice sustainability. All of this leads to the belief that there is an interest on the part of researchers and authors to deepen their research questions in this area, with different approaches to understand the value chain and the sustainability of rice.
\end{abstract}

Keywords: Rice; Value chain; Continuous improvement; Sustainability.

\section{Resumo}

A sustentabilidade é um tema de interesse da ciência e das organizações, sendo uma área de pesquisa emergente no campo agroalimentar e gestão empresarial. Esta área objetiva a investigação dos processos que conduzem as organizações à sustentabilidade, bem como àqueles que conduzem à aprendizagem organizacional e a consequente melhoria contínua. O objetivo deste trabalho é conhecer a evolução e tendência dos estudos sobre a sustentabilidade da cadeia de valor do arroz. Neste sentido, realizou-se como procedimento metodológico uma revisão bibliométrica da literatura no banco de dados Scopus, nos anos de 2001 a 2021, pretendendo-se com isto observar as publicações com o tema sustentabilidade da cadeia de valor do arroz existentes no decorrer dos 20 anos deste século. Dentre os resultados obtidos, verificou-se as publicações sobre o tema abordado tiveram um crescimento exponencial a partir do ano de 2015, ou seja, de 80 publicações para mais de 400 em 2019, podendo-se observar que tal tema passou a ter a devida importância, com vistas à sustentabilidade. Como resultado importante deste estudo observa-se que no ano de 2019 houve mais de 200 publicações com o tema sustentabilidade do arroz. Tudo isso leva a crer que há interesse por parte dos pesquisadores e autores em aprofundar suas questões de pesquisa nesta área, com abordagens diversas com a finalidade do conhecimento da cadeia de valor e a sustentabilidade do arroz.

Palavras-chave: Arroz; Cadeia de valor; Melhoria contínua; Sustentabilidade.

\section{Resumen}

La sostenibilidad es un tema de interés para la ciencia y las organizaciones, un área de investigación emergente en el campo agroalimentario y la gestión empresarial. Esta área tiene como objetivo investigar los procesos que llevan a las organizaciones a la sostenibilidad y los que conducen al aprendizaje organizacional y la consecuente mejora continua. Este trabajo busca comprender la evolución y tendencia de los estudios sobre la sostenibilidad de la cadena de valor del arroz. En este sentido, se realizó una revisión bibliométrica de la literatura en la base de datos Scopus como procedimiento metodológico, en los años 2001 al 2021, para observar las publicaciones sobre el tema de la sostenibilidad de la cadena de valor del arroz existentes a lo largo de los 20 años de este. siglo. Entre los resultados 
obtenidos, se verificó que las publicaciones sobre el tema abordado tuvieron un crecimiento exponencial desde el año 2015, es decir, de 80 publicaciones a más de 400 en 2019, y se puede observar que este tema ha cobrado la debida importancia. , con miras a la sostenibilidad. Como resultado esencial de este estudio, se observa que en 2019 hubo más de 200 publicaciones sobre el tema de la sostenibilidad del arroz. Todo esto lleva a pensar que existe un interés por parte de investigadores y autores por profundizar sus preguntas de investigación en esta área, con diferentes enfoques para entender la cadena de valor y la sostenibilidad del arroz.

Palabras clave: Arroz; Cadena de valor; Mejora continua; Sostenbilidad.

\section{Introduction}

According to Papademetriou (2000), rice is the most important staple food in the world. More than half of the world's population depends on rice for about $80 \%$ of their food needs. Over 90 percent of the world's rice is produced and consumed in the Asia-Pacific region.

With current technology and globalized knowledge of production, distribution, and management systems, people have access to different foods in the world. So too is rice, which is generally available in supermarkets across the globe for its consumers. There are many actors involved in the rice value chain. For example, producers, collectors, millers, traders, retailers, exporters, and final consumers. Therefore, the rice value chain is complex and multifaceted, inferred Maneechansook (2011).

According to Nkuba et al. (2016), there are three levels in the rice value chain: micro, average, and macro. There are input suppliers, producers, collectors, processors, distributors, retailers, and consumers at the micro-level. In the middle, there are groups and associations of farmers, credit institutions, research and extension services, and other service providers. And at the macro level are local government officials, central government, and providers of public services such as electricity, roads, irrigation infrastructure, and storage facilities.

The difficulties in measuring and managing sustainability in industrial organizations are related to the business position about sustainability since the organizational culture, subjectivity, vision, and the implementation of sustainable tools are linked to the actions developed by the industries to achieve sustainability. In this sense, the path to corporate sustainability depends on the element of movement (attitudes) on the part of decision-makers (managers), according to Feil et al. (2019).

In this context, we decided to carry out a bibliometric review on the sustainability trends of the rice value chain. This review was based on articles, journals, authors, and keywords (rice, sustainability, value chain) identified in the chosen bibliographic portfólio.

This research started from the following question: what is the sustainability trend of the rice chain? Because of this issue, we sought to meet the following objectives: a) to identify publications on the Scopus platform that reports on rice; b) collect published data on rice in the twenty years of this century, that is, from 2001 to 2021 ; and c) treat this data in a bibliometric way to provide trends on the sustainability of the rice value chain.

This article is divided into six sections: the introduction, where contextualization was carried out, evidencing the objective, followed by the literature review, the presentation of the methodology, the results and their discussion, and, finally, the final considerations on the subject under analysis.

\section{Literature Review}

There are two species of rice that are grown in the world. The scientific names are "Oryza sativa L" and "Oryza glaberrima Steud", and according to Oka (1988) it belongs to the genus Oryza and has twenty species listed by Roschevicz in 1931, and 23 by Chatterjee, in 1948, based on in the reexamination of specimens in the main herbaria in the world.

Rice planting is one of the most important agricultural activities and is the third most produced agricultural commodity in the world, behind only sugarcane and corn, according to Abaide et al. (2019). And it infers that China is the 
biggest producer of rice (146 million tons), followed by India (103 million tons). These two countries are responsible for approximately $53 \%$ of global rice production. In a global context, Brazil is the largest rice producer outside the Asian continent. In the 2015/2016 harvest, the rice cultivated area in Brazil was approximately 2 million hectares and production was approximately 12 million tons, reiterates Abaide et al. (2019).

The European Union's rice sector represents $0.6 \%$ of world production and the Common Agricultural Policy (PAC) gives producers direct payments, which provide basic support for producers' income, stabilizing their income and also benefiting from aid from rural development policy. The average public support for the gross income of rice producers in the Organization for Economic Cooperation and Development (OECD) in 2004 was 75\%. Therefore, it can be said that rice cultivation in developed countries is one of the most supported by the respective governments (Martínez Pérez, 2018). The same author also mentions that rice is one of the most important crops in Spain, with a total production of over 120,000 tons, and most of the area dedicated to rice is in the Albufera Natural Park in Valencia, whose culture is vitally important, both for the maintenance of this ecosystem and for the economy and income of the people who cultivate it.

According to Chen et al. (2019) for the better socio-economic performance of the circular rice supply chain, new developments are needed, such as the development of technology to reduce the unit's production cost and the development of infrastructure to support the production of biofertilizers.

For Custodio et al. (2019) rice consumers are heterogeneous about the perceived differentiation of rice quality between regions, countries, cities, and levels of urbanization. Premium quality is defined by the nutritional benefits, softness, and aroma in Southeast Asia and the physical appearance of the grains (uniformity, whiteness, slimness), satiety and aroma in South Asia, as these trends are consistent with the perceptions of the industry and have important implications for regional and national breeding programs in terms of adapting germplasm for regions and rice varieties for specific segments of the local market. As rice is traded internationally, it is necessary for technologists to standardize definitions of classes and measures, quality indicators and routines, as well as to implement descriptive profiles of rice, in order to obtain worldwide unanimity in this production, they affirm Custódio et al. (2019).

West African rice has growing difficulties to compete with imported rice in urban markets, infer Demont et al. (2017). These challenges provide crucials insights into improving the value chain in the policymakers' struggle to achieve rice selfsufficiency in West Africa. The results of this research show that the ideal investment portfolio for improving the value chain is a function of the final market, which limits the distance from the port and the cultural function of rice.

Vietnam is one of the largest rice exporters in the world and there is an urgent need for sector area, according to Demont and Rutsaert (2017). The finished parties perceive that the sector's capacity to take advantage of opportunities in the growing domestic and foreign markets is greater than its resilience to potentials, such as climate change and regulations. To adapt to market demands, Vietnamese producers must apply strategies to make the rice value chain more sustainable, developing the product and creating production standards (process improvement).

Also, according to the United Nations (UN, 2020), which has the purpose of "achieving international cooperation to solve international problems of an economic, social, cultural or humanitarian nature", in 2000, the 192 member states agreed to achieve eight millennium development goals by 2015. Among these goals is to ensure environmental sustainability. Subsequently, and as of 2015, the 17 objectives were adopted to be achieved by the countries of the world by 2030, as an agenda of actions to be pursued by all. In this case, we highlight that "sustainable consumption and production means doing more and better with less" and also "separating economic growth from environmental degradation, increasing resource efficiency and promoting sustainable lifestyles".

The rapid transformation of agrifood value chains due to population growth, urbanization, increased consumer income, and increased demand for food quality and safety has resulted in the need for small farmers to coordinate horizontally 
through the formation of groups and collective marketing for improving agricultural performance in developing countries, infer Abdul-Rahaman and Abdulai (2020).

According to Morioka and Carvalho (2016), these structures still lack comprehensive integration with strategic maps and value creation, although sustainability structures involve strategic approaches and this seems to indicate that sustainability is still measured as a separate performance evaluation system of the institution.

Circular Economy aims to promote the creation of value by reducing resources, costs, and impacts. In this respect, it seems to constitute a paradigm for sustainability as a generator of a regenerative metabolism of the metabolic cleft provided by the built environment, but although Circular Economy is called a paradigm in several investigations, it has not yet been research that characterizes it with the aspects that a paradigm must have, infer Ávila-Gutiérrez et al. (2019).

According to Feil et al. (2019), sustainable development can be achieved through a new vision attributed to industrial processes, concerning the control of gas collection, reuse, and recycling of waste, types, and quantities of environmental resources, among others. This view is not considered an easy task to achieve, as it involves high levels of corporate management, production, and consumption by society. Furthermore, sustainability indicators must be identified and selected by observing desirable qualities and essential characteristics (Feil et al., 2019).

Perilla et al. (2012) observed that the Global Management of Susceptibility and the Socioecological and Environmental Systems is useful for identifying problems, proportions of management, and assessing susceptibility, considering agricultural uses and environmental goals in a regional context. The use of the developed methodology identified several periods in which the sustainability of the socio-ecological system, as a whole, could be achieved.

Marques and Carvalho (2017) believe that the economic viability and sustainability of production and holdings dedicated exclusively or partially to agricultural activity must be supported by agricultural policies. Aid payments from small farmers temporarily make these smallholdings viable, but their sustainability can only be ensured either in a framework of pluriactivity (in the case of very small and smallholdings) or in a framework of valorization and development of the agricultural activity, what average technical support, per unit of work, acceptable and competitive about other occupations or professions.

Methods with several criteria, such as the Analytical Network Process, must be seriously considered to improve the use of sustainability analysis, for the inclusion of agricultural and agri-environmental policies, because they give due attention to the multiple facets of the concept of sustainability and reinforce their related practice, says Reig et al. (2010).

Sustainable industrial systems within the company's sustainability and continuous improvement perspectives constitute a green innovation and sustainability is considered indispensable. Green and lean, in the Plan, Do, Check, Action (PDCA) cycle and, specifically, the application of Value Stream Mapping (VSM) are tools to improve sustainability (GarzaReyes et al., 2018).

An extensive analysis of the literature, on sustainable livelihood structures and agroecological literature, maintains the creation of a structure to meet the local context and, which, at the same time, must-have for development and conservation projects, these being they did not contribute to the participatory approach and allowed an inclusive environment, where a structure is relevant for all involved (Addinsall et al., 2015).

Sustainability has its antecedents, which is performance. To achieve performance, the involvement of leadership and the organization is necessary, in addition to performance as a mediating variable (Soebandrija, 2017). And add, Goldenberg \& Wiley (2011), that the generation of ideas and divergent thinking are central creative components of problem-solving.

Problems in the rice value chain incorporate adaptable transport, advertising, and marketing, and this is well demonstrated by the shift to the rice-based agri-food system, with the rice value chain transforming into several compatible biological responses and possible (Ngamcharoenmongkol et al., 2019; Nkuba et al., 2016). 
Value Chain Analysis (VCA) can expose strategic and operational misalignments within the chains and the consequent displacement of resources and, therefore, opportunities for improvements that create value and economic sustainability. It is necessary to develop VCA variants that incorporate the three pillars of sustainability and identify consistent business opportunities for value chains to create value shared between business and society (Fearne et al., 2012). A new type of Value Stream Mapping or supply chain, of seven maps, is based on the different residues inherent to value flows. The use of the various tools, individually or in combination, is therefore driven by the types of waste to be removed and provides a simple mechanism for choosing which is the most appropriate for contingent situations (Hines \& Rich, 1997).

An organization's value chain consists of primary and secondary activities, which are divided into several subparts (Bhargava et al., 2018). The technology involved in the primary activities includes support activities, inbound logistics technology, etc. Competitive advantage activities were divided into advantage and cost differentiation, which have several cost and differentiation factors. In the strategic management literature, the analysis of the value chain is considered an essential analytical tool, therefore, its value cannot be compromised, it just needs to be developed and practiced.

According to Oliveira and Fernandes (2017) and Melton (2005), the use of Lean tools is a simple and low-cost way to achieve productivity and profitability, using a continuous focus on eliminating waste throughout the organization. Lean tools are easy to use, involve the entire organization and ensure everyone's commitment, from top to bottom, ensure that it is a way to empower employees and make the results of their work visible. The Kano model is built according to customer requirements, which change over time and the situation. Quality attributes affect customer satisfaction. The decision-making diagram corresponds to the life cycle of the quality attributes proposed by Kano. Of utmost priority are the product requirements that the customer considers important and which show disadvantages with the competitors' products. The longterm objective is to improve customer satisfaction about important product characteristics, to establish sustainable competitive advantages (Lin, 2017; Madzík, 2018; Sauerwein et al., 1996).

The already extensive number of academic publications is increasing at a rapid pace and it has become impossible to keep up to date, with the empirical contributions of large and fragmented research flows. Aria and Cuccurullo (2017) further infer that "this hinders the ability to actively accumulate knowledge and collect evidence through a set of previous research papers". In literature reviews, academics use different qualitative and quantitative approaches to understand and organize previous findings. It also infers (Aria \& Cuccurullo, 2017) that bibliometrics has the potential to introduce a systematic, transparent and reproducible review process based on the statistical measurement of science, scientists, or scientific activity, providing more objective and reliable analyzes.

Groos and Pritchard (1969) concluded that the definition and purpose of the statistical bibliography, later replaced by the word "Bibliometrics", were declared in several ways such as a) shedding light on the processes of written communication and the nature and course of the development of a discipline, by counting and analyzing the various facets of written communication; and b) the assembly and interpretation of statistics relating to books and periodicals, to demonstrate historical movements, to determine the use of a book, periodicals, and paper research.

With this much new information, conceptual developments, and data, bibliometrics is useful, providing a structured analysis for a large body of information, inferring trends over time, themes, verifying changes in disciplines, detecting more prolific academics and institutions, as well as the general time of the research, says Aria and Cuccurullo (2017).

For Broadus (1987), there is a delineated body of research involving physical numbers of publications, bibliographic citations, and substitutes for them. The measurement of these items is called, of course, "bibliometry". 


\section{Method}

It is a systematic literature review and without meta-analysis, which seeks to identify and quantitatively study publications on the Scopus platform, Groos and Pritchard (1969).

We chose the following algorithms, based on the keywords of this study: "rice" AND "sustainability", "value chain" OR "continuous improvement". The other filters were: Years 2001 to the present (day 02/20/2021). Only "articles" and in the English language. From the Scopus platform, we saved a file with the raw data "Scopus.bib", in BibTex format and another file "scopus.csv", which generated the data for use in Software R and Rstudio and later the data treatment in Biblioshiny. Biblioshiny generated graphs, tables, and other figures to explain the results and discuss, Aria and Cuccurullo (2017).

All articles were used for this research, since they deal with the continuous improvement of the rice value chain and its sustainability, without however a specific treatment of these algorithms.

The figure below showed the main information about the data. It is observed that the space of time appears as from 2005 to 2021, with 1481 documents, although the study started in 2001 (inclusive), which will be seen in another graph.

Figure 1 - Main Data Information.

\begin{tabular}{|c|c|}
\hline Description & Results \\
\hline \multicolumn{2}{|l|}{ MAIN INFORMATION ABCUT DATA } \\
\hline Timespen? & $2005: 2021$ \\
\hline Sources (Journals, Books, etc) & 616 \\
\hline Docurrents & 1481 \\
\hline Average years from putaication & 3,39 \\
\hline Average citations per documents & 14.53 \\
\hline Average ditalions per year per doc. & 2.394 \\
\hline References & 116088 \\
\hline \multicolumn{2}{|l|}{ DOCUMENT TYPES } \\
\hline article & 1481 \\
\hline \multicolumn{2}{|l|}{ DOCUMENT CONTENTS } \\
\hline Keywords Plus (10) & 5266 \\
\hline Authors Keywords (DE) & 4818 \\
\hline \multicolumn{2}{|l|}{ AUTHORS } \\
\hline Authoen: & 5467 \\
\hline Author Appearances & 6353 \\
\hline Authors of singlesuthoced documents & 117 \\
\hline Asthors of mult-authored documents & 5950 \\
\hline \multicolumn{2}{|l|}{ AUTHORS COLLARORATION } \\
\hline Single-authored documents & 127 \\
\hline Documents per Author & 0.271 \\
\hline Authors per Document & 3.69 \\
\hline Co-Authoes per Doouments & 4.29 \\
\hline Colloberatian Index & 3.93 \\
\hline
\end{tabular}

Source: Scopus and Publishiny (2021).

\section{Results and Discussion}

In this section, the results of the analysis of data obtained on the sustainability trend of the rice value chain, the annual scientific production, the most cited sources, and the most relevant to our study are presented, as well as the countries with the largest number of researches.

A total of 1481 articles comprised the collection of bibliometric research obtained from the Scopus database, one of the most complete and worldwide known and used, as shown in the figure below.

Figure 2 shows the number of articles distributed in the period from 2001 to the present. It is noticed that in 2010 the trend of increasing articles began, culminating with the year 2020, when the largest number of articles published on the rice chain, as well as its sustainability, was seen, consequently it was the year that most contributed to the study, with 415 articles, as seen in Table 1. There is an increase in publications that show this trend on sustainability motivated by the concern of 
countries, as cited by the UN (2020) whose goal of sustainable development in relation to the "Sustainable consumption and production means doing more and better with less" and also means decoupling economic growth from environmental degradation, increasing resource efficiency and promoting sustainable lifestyles. Since then, the authors have dedicated themselves to studies for this sustainable development of productions and productive means.

Figure 2 - Documents per year.

\section{Documents by year}

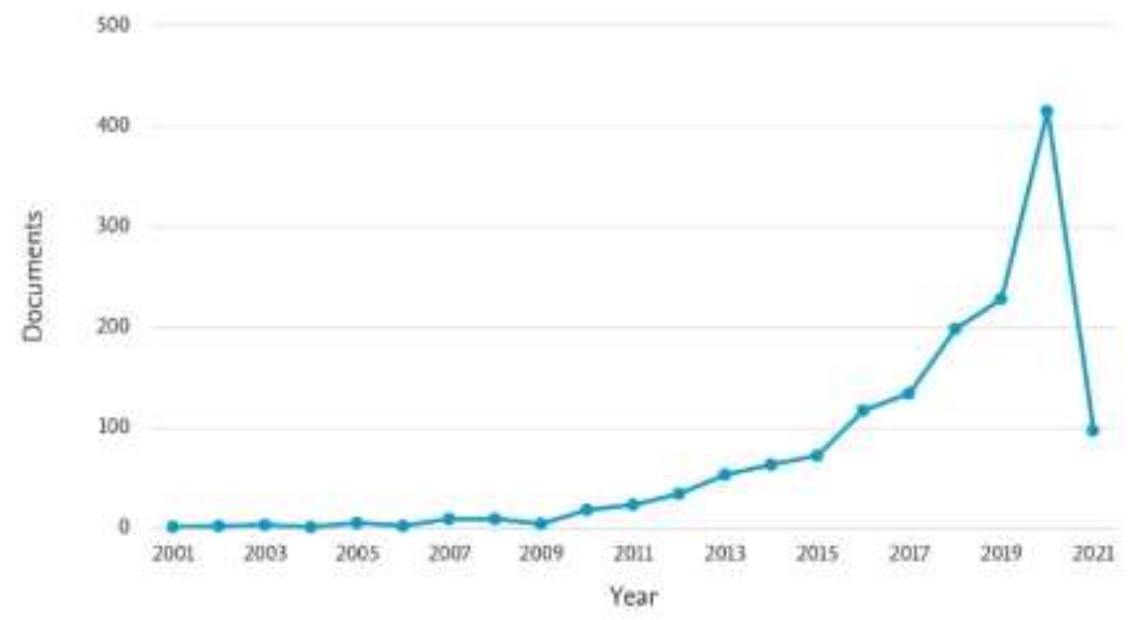

Source: Scopus and Publishiny (2021).

Table 1 - All documents by year.

\begin{tabular}{|c|c|c|c|c|c|c|c|c|c|c|c|c|}
\hline Ano & 2001 & 2002 & 2003 & 2004 & 2005 & 2006 & 2007 & 2008 & 2009 & 2010 & 2011 & \\
\cline { 1 - 10 } Doc. & 1 & 1 & 1 & 1 & 5 & 1 & 6 & 6 & 1 & 20 & 27 & \multirow{2}{*}{ Total of 1481 documents } \\
\hline Ano & - & 2012 & 2013 & 2014 & 2015 & 2016 & 2017 & 2018 & 2019 & 2020 & 2021 \\
\hline Doc. & - & 34 & 53 & 63 & 72 & 117 & 134 & 198 & 228 & 415 & 97 & \\
\hline
\end{tabular}

Source: Scopus and Autors (2021).

In Figures 3 and 4 we identify the main and most important sources that published about the rice production chain, from which we highlight the following: Journal Clean Production, Food Policy, World Development, Sustainability and Science, with the absolute majority of publications, being that the Sustainability Magazine presents itself as the most relevant, since it has published more than 600 publications with this theme on rice. 
Figure 3 - Most cited sources.

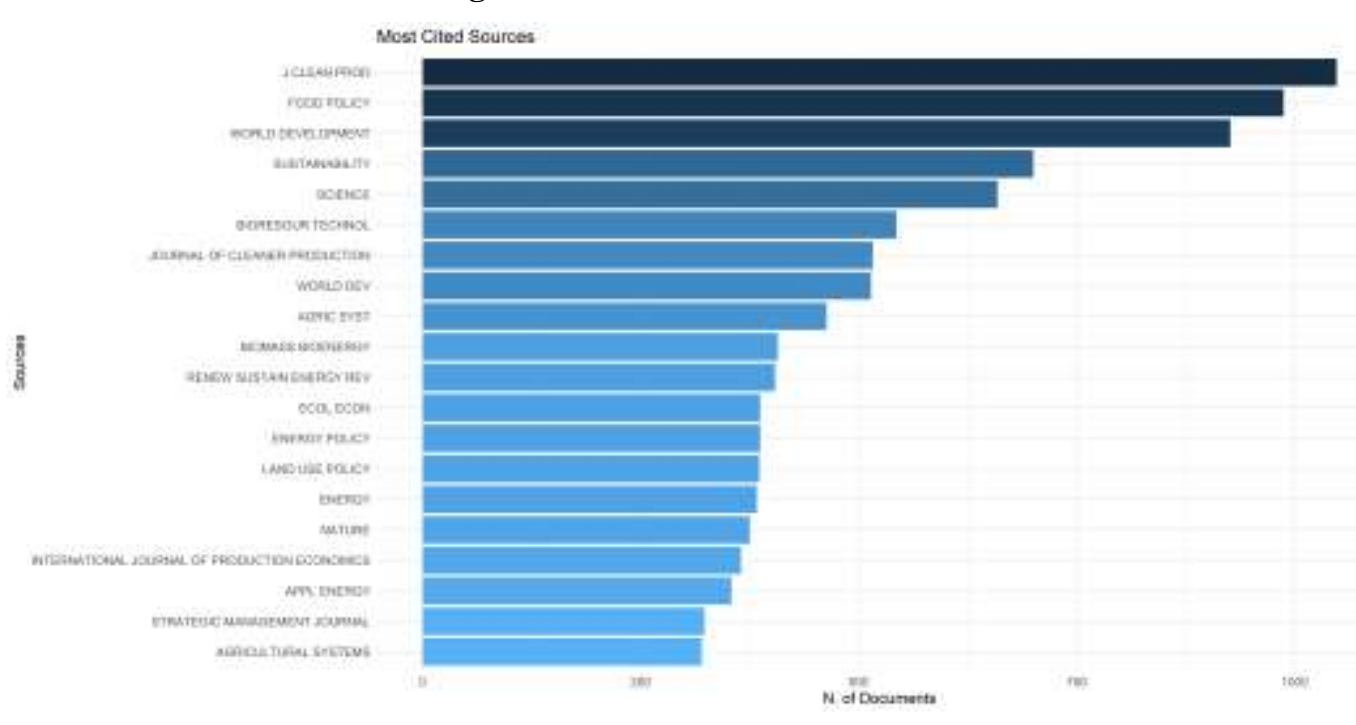

Source: Scopus and Publishiny (2021).

Figure 4 - Most relevant sources.
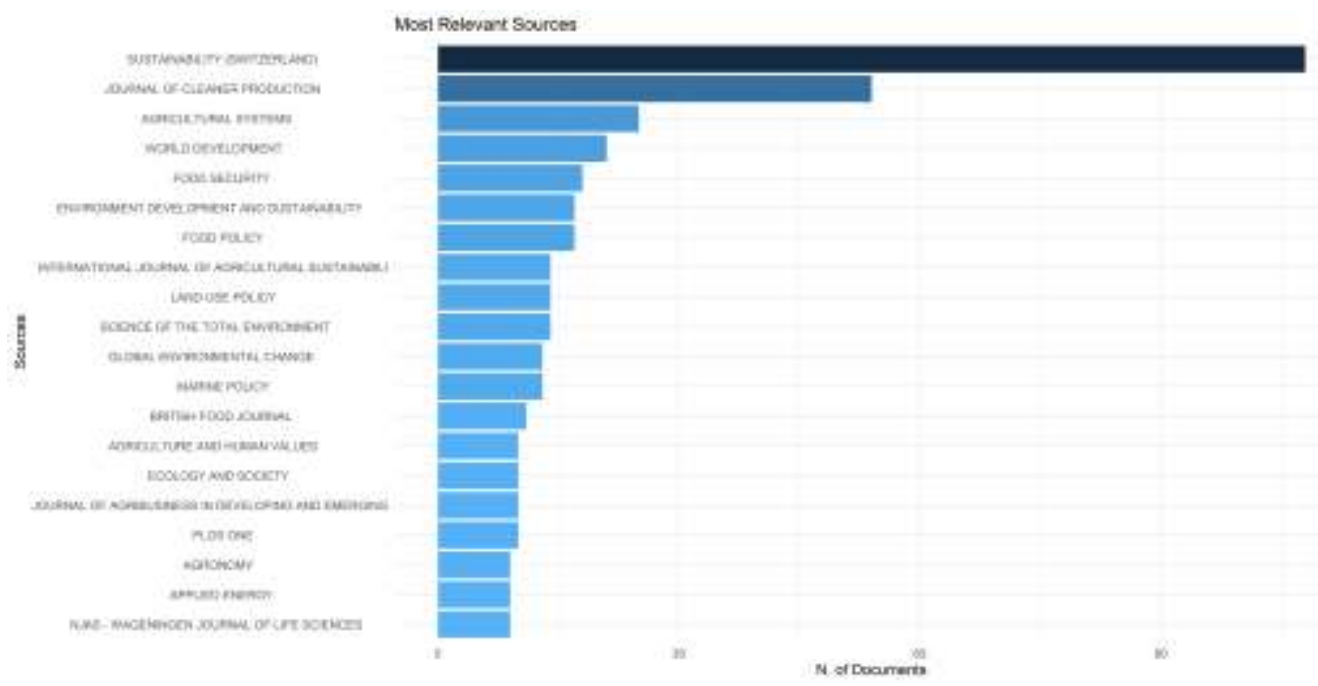

Source: Scopus and Publishiny (2021).

Figure 5 shows us the countries that have published the most about the sustainability of the rice value chain, coming first from the United States of America, then the United Kingdom and Germany, with an overwhelming number of publications. It is observed that Brazil and Portugal appear with just over 50 publications, verifying that Brazil and Portugal are not focused on these studies on the sustainability of the rice chain, even though Brazil is the second largest producer in the world outside Asia and the 9th largest producer in the world (FAO, 2020). 
Figure 5 - Documents by country.

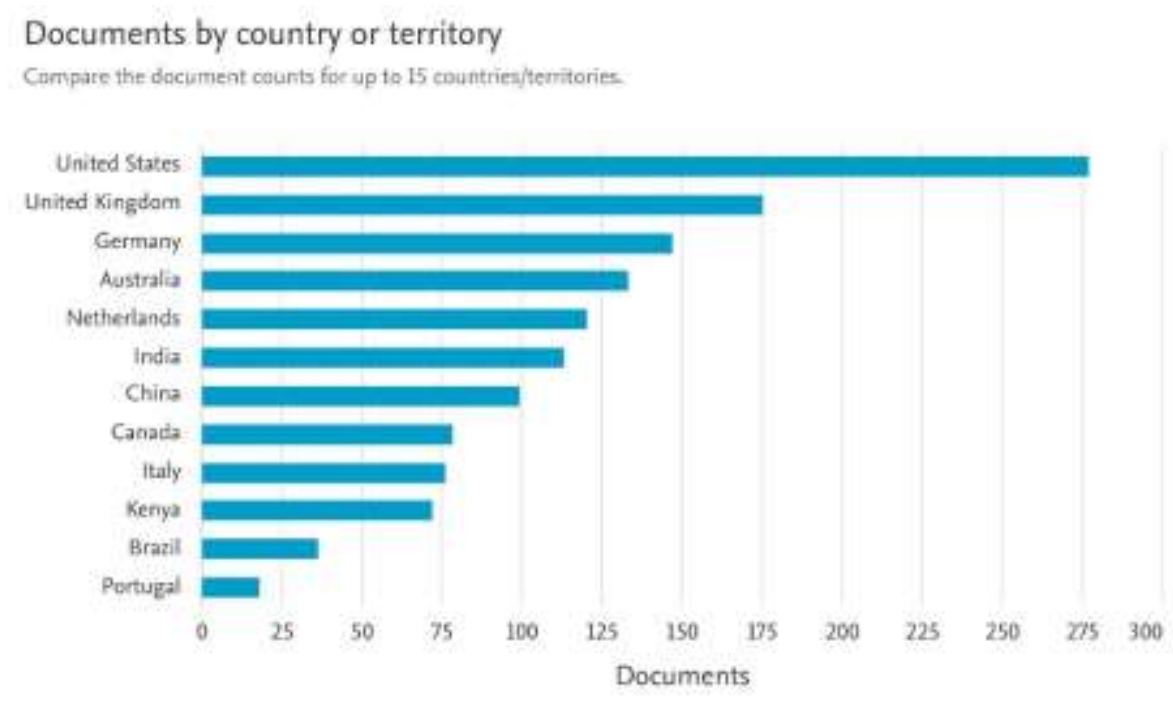

Source: Scopus and Publishiny (2021).

Figure 6 above shows the collaborative state between countries, where it can be seen that in Europe, and particularly Switzerland, it is the country that collaborates most with the United States of America, Australia, China, East Africa, Canada and Brazil. Collaboration is identified by the red lines and consequently by the information and citations exchanged by the researches disclosed in the proposed theme, sustainability of the rice chain, as well as inferring from the intensity of lines, the large number of scientific papers published in those countries. These exchanges of information, scientific research and good practices will be used for the sustainable development of the chain in question.

Figure 6 - Collaboration map between countries.

\section{Country Collaboration Map}

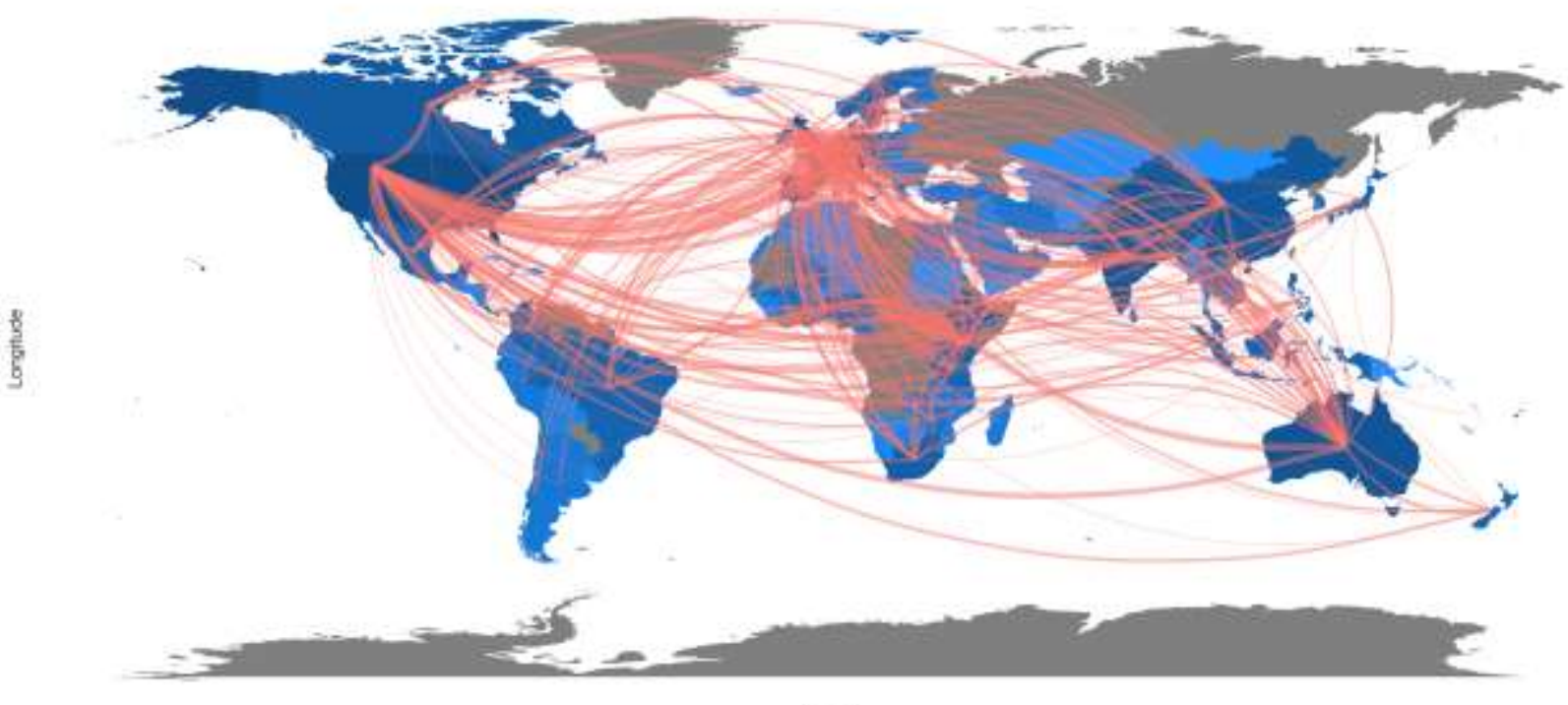

Latude

Source: Scopus and Publishiny (2021). 
Figure 7, shown below, shows the production of the main authors, mainly in the years 2014, 2017 and 2018. Sustainability is highlighted with the author Demont, from 2017, whose circumference dimension is directly proportional to the quantity published by the author. In the background Bacon C.M., 2014 with the term Global Environmental Change and in the third plan, Ragasa C., which in 2018, introduces us to the term World Development. Here in this figure, it can be seen that sustainability starts to have importance as of 2017, together with the world Development.

Figure 7 - Document clusters.

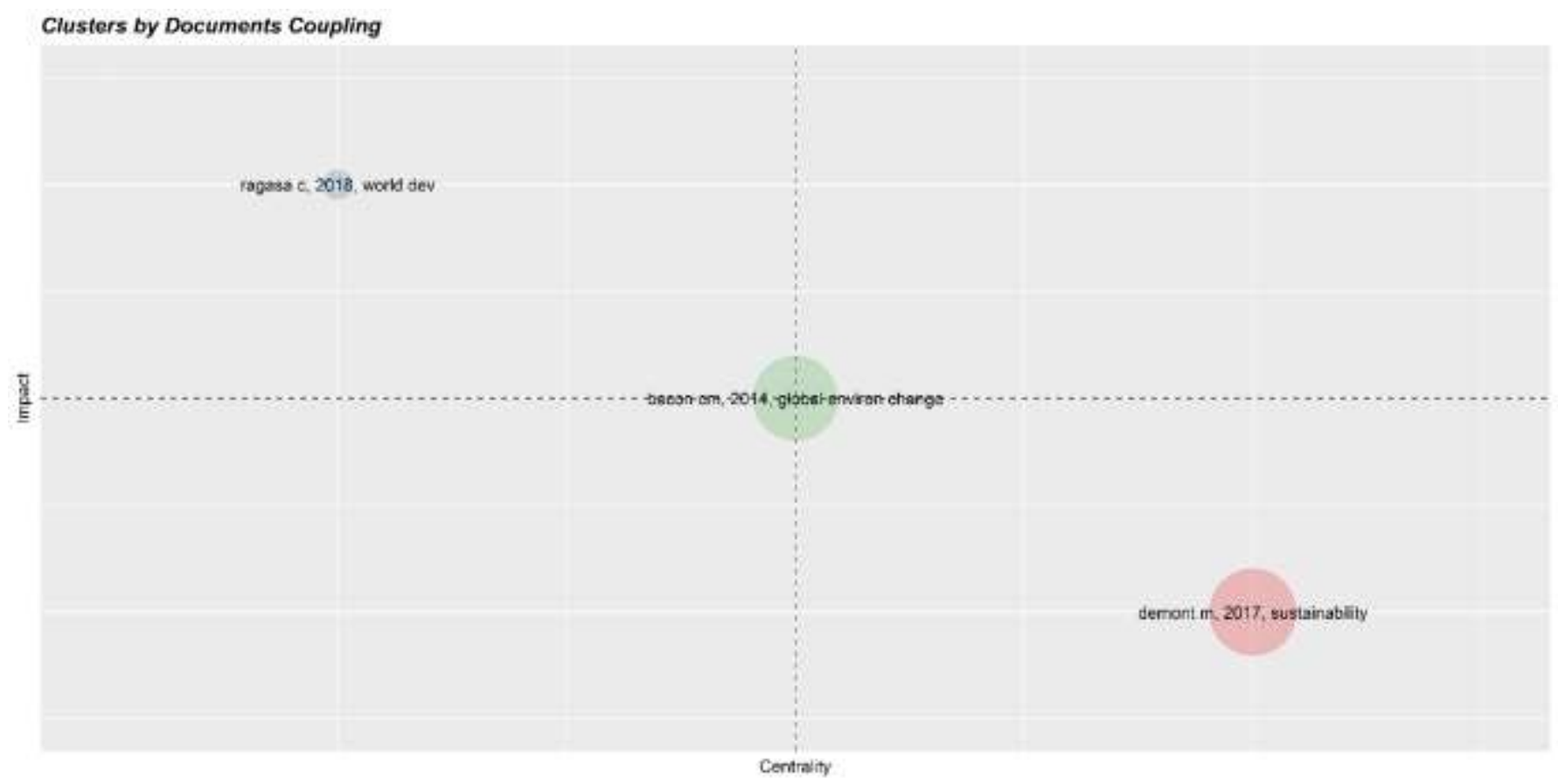

Source: Scopus and Publishiny (2021).

Figure 8 shows the Direct Citations between the authors, which shows that in 2017 and 2020 most of the citations by authors who published on the value chain and sustainability of rice occurred. In 2016, there is an author with the highest number of direct citations by the other authors. Then, we have Beuchet and Morris, most cited in 2013; Van Nijsgbergen, the most cited in 2016; Juliane, Snider, Mithfor and Solr, as the most cited in 2017. The authors who cited the most were: Vanderhaegen and Valencia, in 2018; Bray, Dietz and Bielecki, in 2019. Finally, the authors who most cited other authors in 2020 were: Van Zonneveld, Meenken, Maguire-Rajpol and Mook. 
Figure 8 - Historical Direct Citation Network.

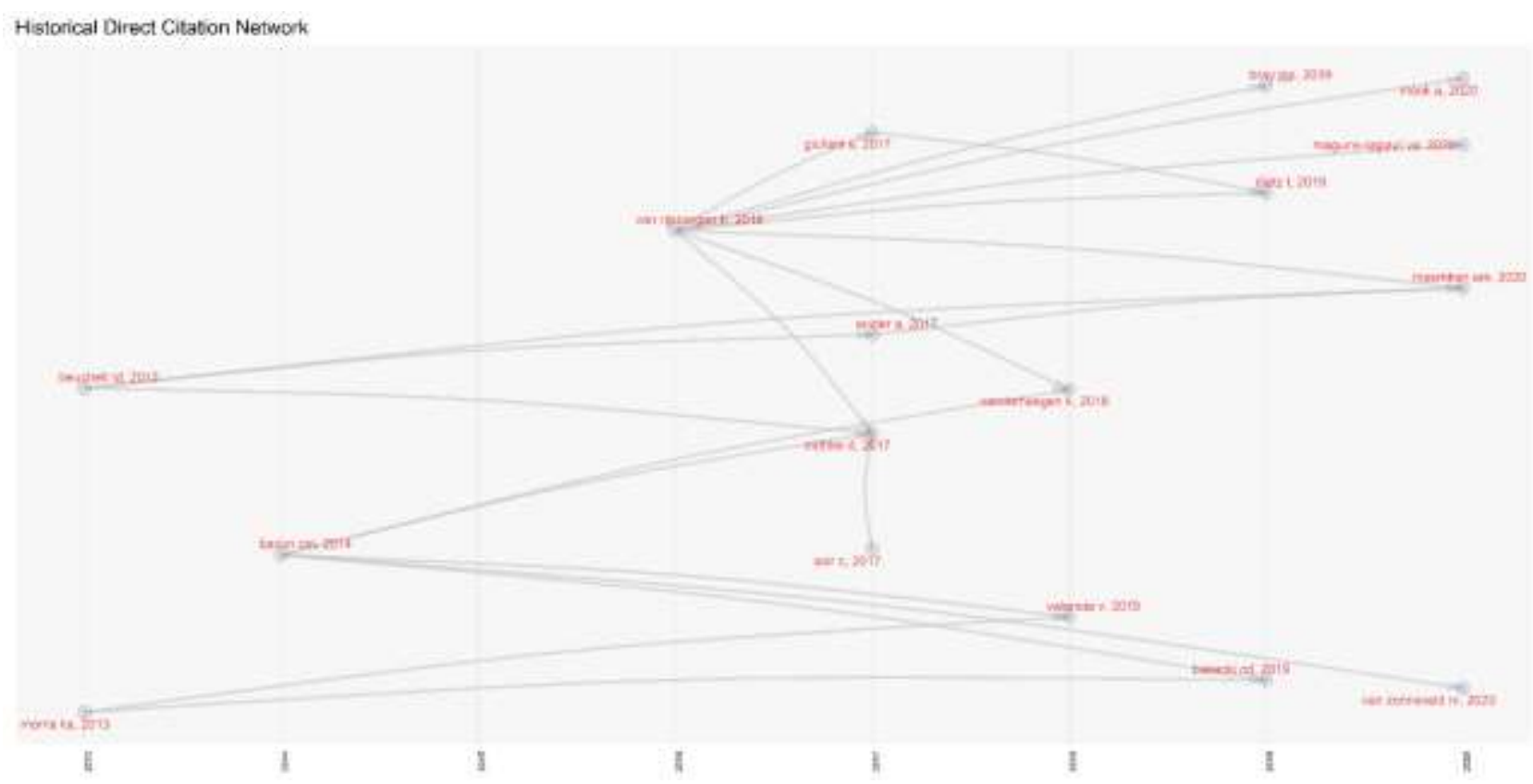

Source: Scopus and Publishiny (2021).

Figure 9 shows the authors who published the most, thus contributing to the theme of sustainability in the rice value chain. The authors who produced the most articles and contributed to the growth of this area of study were: Klerkx L., with 9 articles; Bacon C.M., Belton B. and Ma W., with 8 articles each; and Amutio M., Demont M., Lopez G., Maertens M., Olazar M., Rueda X., and Sieber S., all with 7 publications each.

Figure 9 - Most relevant authors.

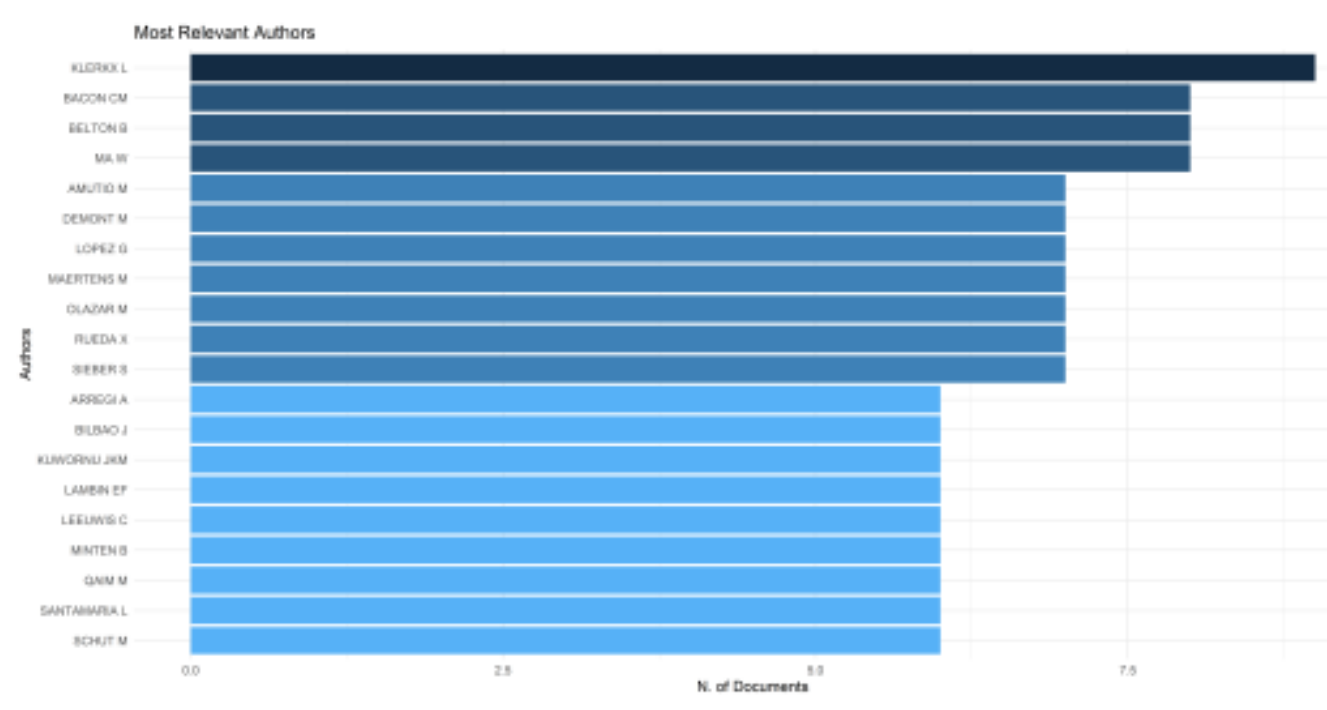

Source: Scopus and Publishiny (2021).

Figure 10 indicates the thematic areas in which the largest number of articles related to the sustainability of the rice value chain have been published. In Environmental Sciences, $20.5 \%$ of the articles were published; in Social Sciences, $18 \%$ of the articles were published; in Agrarian and Biological Sciences 16.4\% were published, in the theme of Energy and Business 
9\% of the articles were published; on the theme of Management and Accounting, $8.6 \%$ of the articles were published; and in the area of Economics, Econometrics and Finance, 7.2\% of the articles were published. These are the thematic areas that have worked the most with the sustainability of the rice value chain, corresponding to about $80 \%$ of published studies.

Figure 10 - Documents by thematic área.

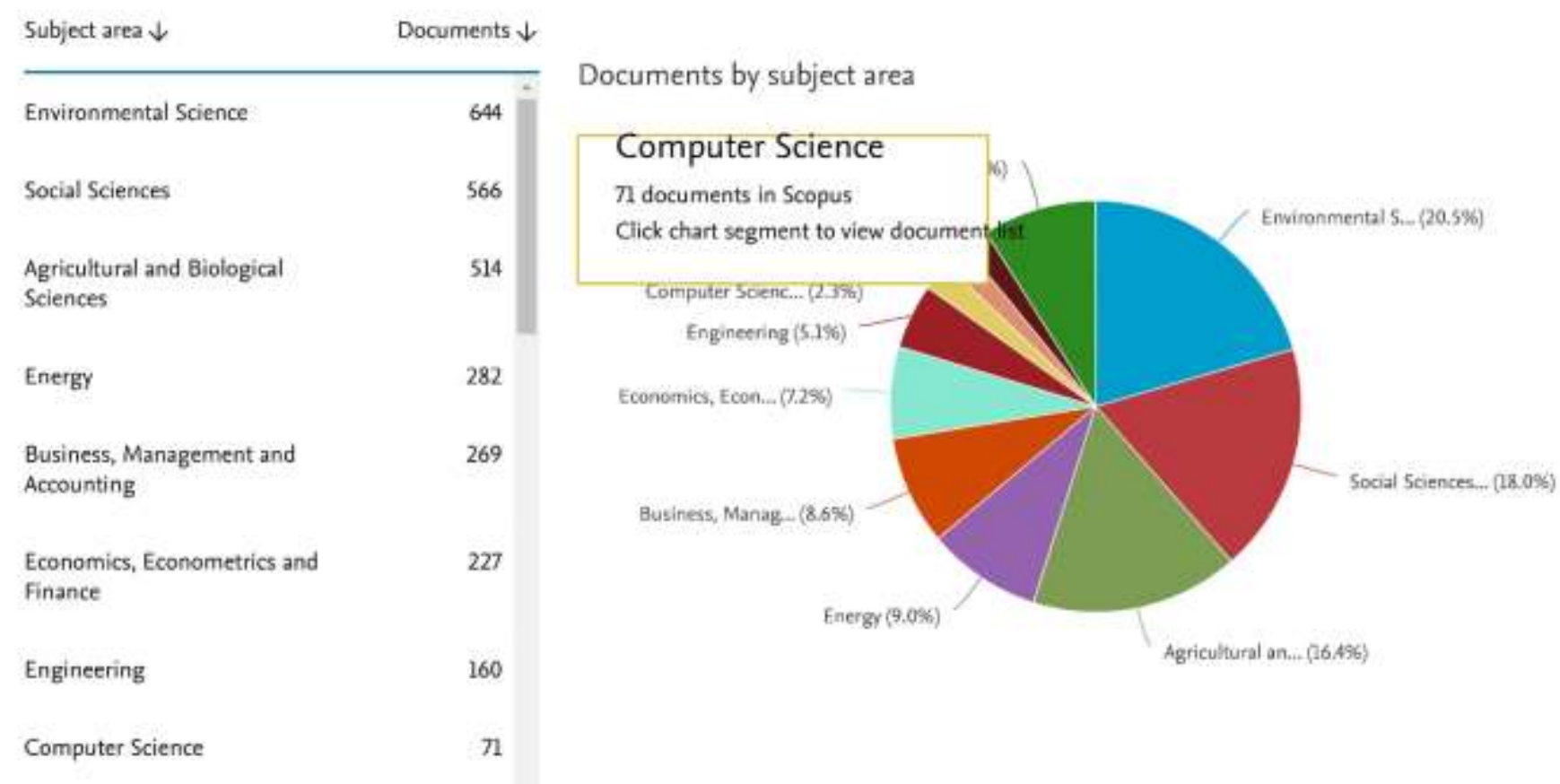

Source: Scopus and Publishiny (2021).

Figure 11 shows the evolution of the themes sustainability, sustainable development, climate change and biomass related to the sustainability of the rice value chain. These were the themes that most evolved as shown in the figure below. An evolution of the sustainability theme is perceived in the years from 2019 to 2021. It is also inferred a relationship between sustainable development and sustainability and climate change, while climate change is related to sustainability and biomass. However, sustainability was the theme that has been most often cited in recent years. 
Figure 11 - Evolution of thematic areas.

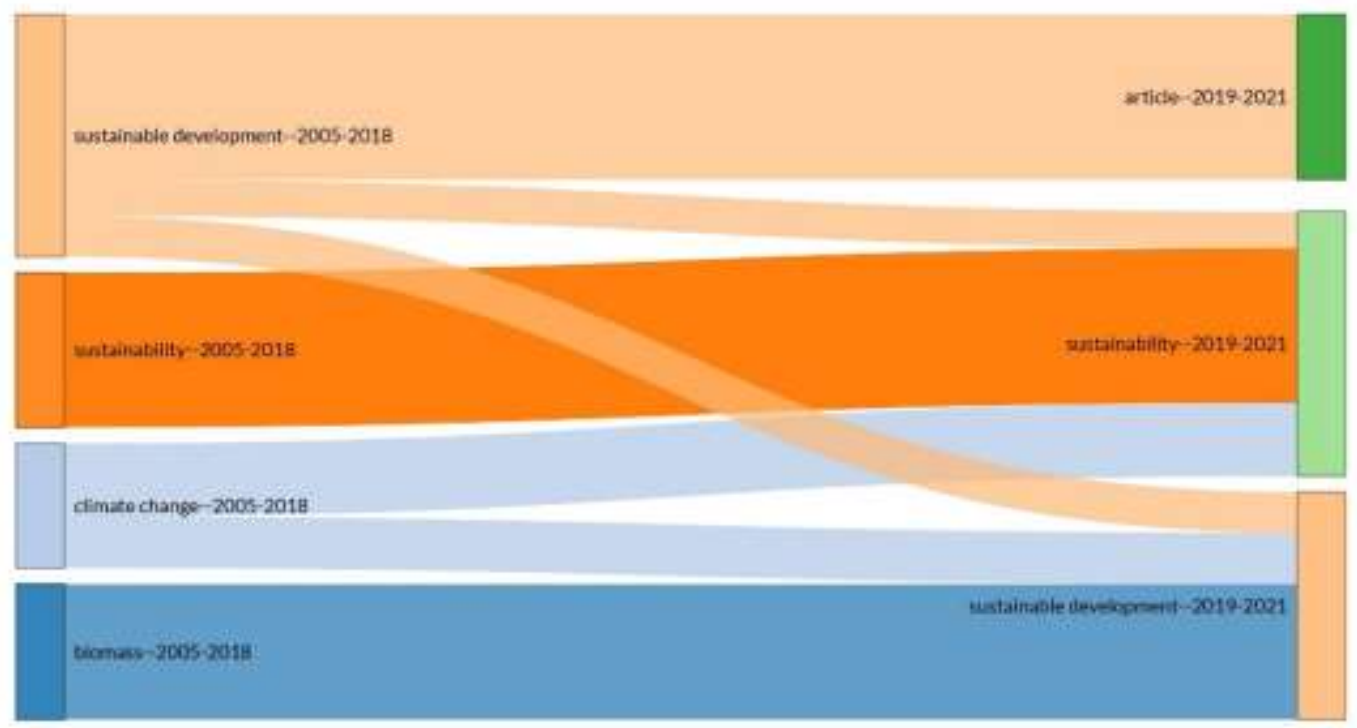

Source: Scopus and Publishiny (2021).

Figure 12 presents the network of co-citations, in order to observe which words have a direct or indirect relationship with the researched topic. It appears that the words with the greatest contribution to the research were "Sustainability" in the foreground and "Sustainable Development", with higher density and greater centrality, thus identifying a greater number of relationships. This centralization demonstrates a greater flow of information for sustainability and sustainable development. There is also a greater proximity between these two themes with the other pertinent themes, such as climate change, crop production, agriculture and food security. 
Figure 12 - Co-citations networks.

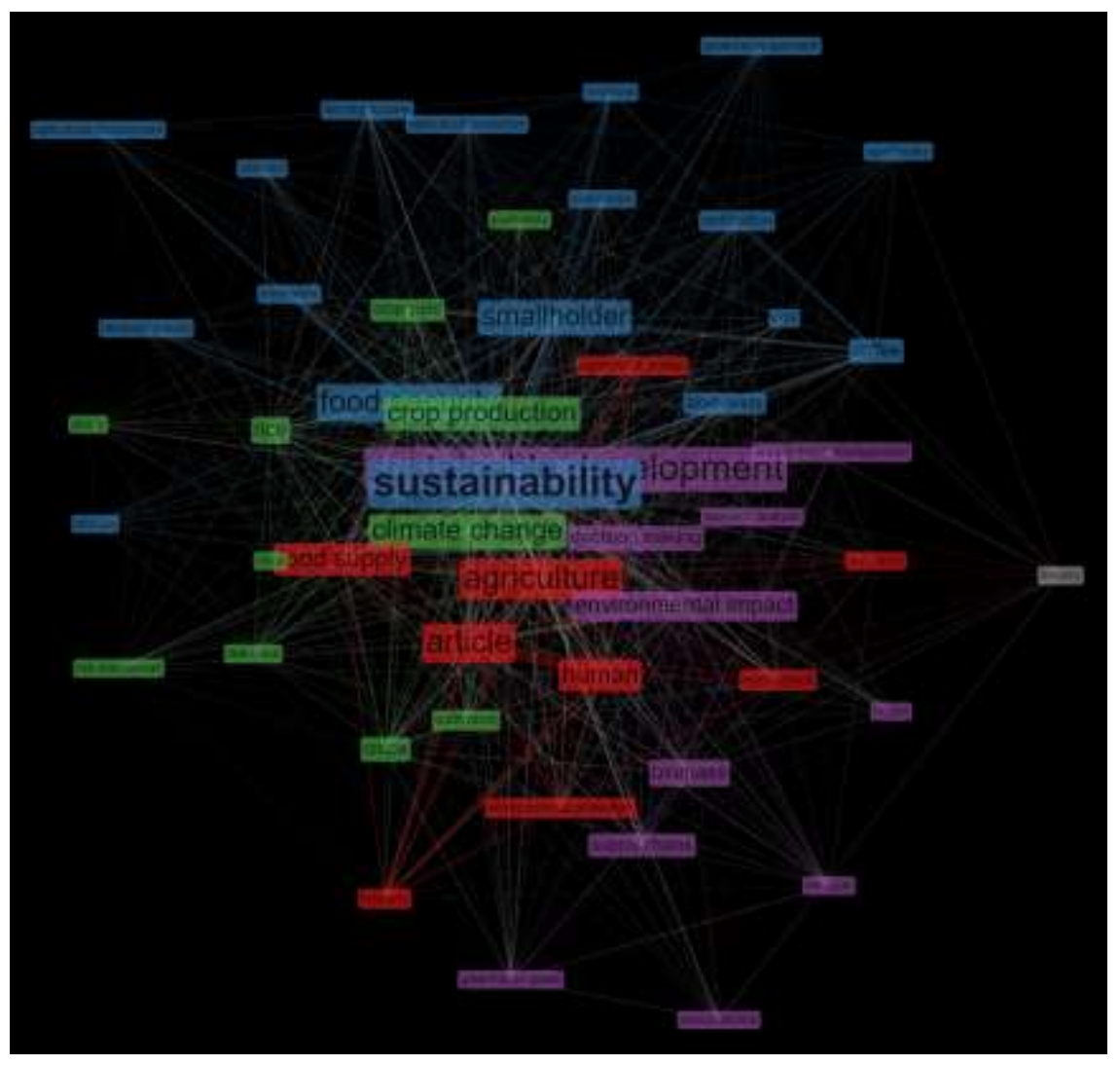

Source: Scopus and Publishiny (2021).

Our study finds its culmination in the presentation of figure 13 below, which shows the behavior and growth of the sources that most published on the sustainability of the rice value chain. Notably Switzerland's "Sustainability" magazine was the source that grew the most from 2017 until today, presenting an upward and relevant growth curve, with regard to the topic of study, with more than 100 publications since 2005. The difference is very big in view of the second source that only published less than 60 articles on the same theme: rice and sustainability. The other sources presented in the graph, practically do not appear in the world scenario of published articles. This demonstrates that the topic in question is sustainability, including having an exclusive journal for the topic. 
Figure 13 - Growth of sources.

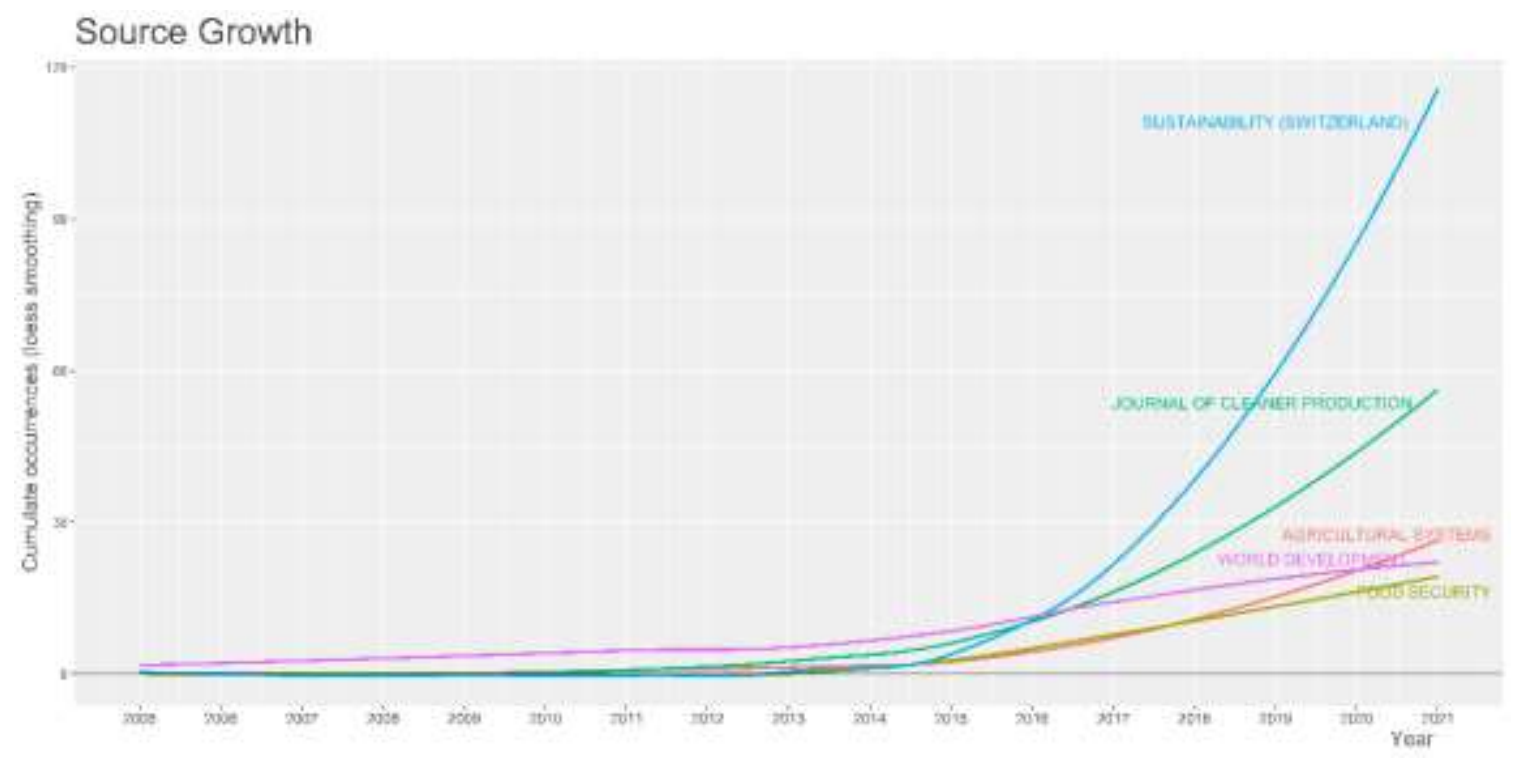

Source: Scopus and Publishiny (2021).

Still discussing the results, we infer that the "sustainability" theme of the rice chain only deserved treatment from the year 2017 when many authors began to publish on this subject. Along with the theme "sustainability", another theme that has been growing in several studies was "sustainable development".

\section{Final considerations and Suggestions for Future Research}

This bibliometric study aimed to identify publications on the Scopus platform that reports on rice; collect published data on rice in this century; and treat this data in a bibliometric way to provide dynamic trends on the sustainability of the rice value chain.

This bibliometric survey allowed us to find the main trends in the rice value chain in terms of sustainability, where we carried out the analysis of existing documents on the Scopus platform in the years 2001 to 2021 (February). In the first 9 years, 23 articles were published. From the years 2010 to 2015, that is, for 6 years, 269 articles were published. And to confirm interest in the theme of rice sustainability, in the following five years (2016 to 2020) 1092 articles were published. After the year 2016, a substantial increase in publications is evident, confirming the trend of sustainability in organizations and in particular those in the rice value chain.

It is a qualitative research, but of such relevance, since it is an original work that opens the discussion to others on this same theme by involving the issues of sustainability in the rice chain.

We also verified that the documents removed from the Scopus platform are treated in their entirety in a crude way, that is, we do not carry out a specific treatment on each publication, which will be for other work in this regard, such as a more in-depth work on the subject, considered one of the limitations of the work.

Future research suggests a deepening of this study so that the value chain, continuous improvement, and global or local sustainability of rice can be observed. 


\section{References}

Abaide, E. R., Tres, M. V., Zabot, G. L., \& Mazutti, M. A. (2019). Reasons for processing of rice coproducts: Reality and expectations. Biomass and Bioenergy, 120, 240-256. https://doi.org/10.1016/j.biombioe.2018.11.032

Abdul-Rahaman, A., \& Abdulai, A. (2020). Farmer groups, collective marketing and smallholder farm performance in rural Ghana. Journal of Agribusiness in Developing and Emerging Economies, 10(5), 511-527. https://doi.org/10.1108/JADEE-07-2019-0095

Addinsall, C., Glencross, K., Scherrer, P., Weiler, B., \& Nichols, D. (2015). Agroecology and sustainable rural livelihoods: A conceptual framework to guide development projects in the Pacific Islands. Agroecology and Sustainable Food Systems, 39(6), 691-723. https://doi.org/10.1080/21683565.2015.1017785

Aria, M., \& Cuccurullo, C. (2017). Bibliometrix: An R-tool for comprehensive science mapping analysis. Journal of informetrics, 11(4), 959-975. https://doi.org/10.1016/j.joi.2017.08.007

Ávila-Gutiérrez, M. J., Martín-Gómez, A., Aguayo-González, F., \& Córdoba-Roldán, A. (2019). Standardization framework for sustainability from circular economy 4.0. Sustainability, 11(22), 6490. https://doi.org/10.3390/su11226490

Bhargava, A., Bafna, A., \& Shabarisha, N. (2018). A review on value chain analysis as a strategic cost management tool. Acc Financ Manag J, 3(3), 1386-93. https://doi.org/10.9756/IAJAFM/V5I1/1810009

Broadus, R. N. (1987). Toward a definition of “bibliometrics”. Scientometrics, 12(5-6), 373-379. https://doi.org/10.1007/BF02016680

Chen, W., Oldfield, T. L., Katsantonis, D., Kadoglidou, K., Wood, R., \& Holden, N. M. (2019). The socio-economic impacts of introducing circular economy into Mediterranean rice production. Journal of Cleaner Production, 218, 273-283. https://doi.org/10.1016/j.jclepro.2019.01.334

Custodio, M. C., Cuevas, R. P., Ynion, J., Laborte, A. G., Velasco, M. L., \& Demont, M. (2019). Rice quality: How is it defined by consumers, industry, food scientists, and geneticists?. Trends in food science \& technology, 92, 122-137. https://doi.org/10.1016/j.tifs.2019.07.039

Demont, M., Fiamohe, R., \& Kinkpe, A. T. (2017). Comparative advantage in demand and the development of rice value chains in West Africa. World Development, 96, 578-590. https://doi.org/10.1016/j.worlddev.2017.04.004

Demont, M., \& Rutsaert, P. (2017). Restructuring the Vietnamese rice sector: towards increasing sustainability. Sustainability, 9(2), 325. https://doi.org/10.3390/su9020325

Food and Agriculture Organization (FAO) (2018). Largest rice producers in the world. In FAO in Brazil. Recovered at 12/15/2020 at http://www.fao.org/brasil/noticias/detail-events/pt/c/1098805/

Fearne, A., Martinez, M. G., \& Dent, B. (2012). Dimensions of sustainable value chains: implications for value chain analysis. Supply Chain Management, 17(6), 575-581. https://doi.org/10.1108/13598541211269193

Feil, A. A., Schreiber, D., Haetinger, C., Strasburg, V. J., \& Barkert, C. L. (2019). Sustainability Indicators for Industrial Organizations: Systematic Review of Literature. Sustainability, 11(3), 854. https://doi.org/10.3390/su11030854

Garza-Reyes, J. A., Romero, J. T., Govindan, K., Cherrafi, A., \& Ramanathan, U. (2018). A PDCA-based approach to environmental value stream mapping (EVSM). Journal of Cleaner Production, 180, 335-348. https://doi.org/10.1016/j.jclepro.2018.01.121

Goldenberg, O., \& Wiley, J. (2011). Quality, conformity, and conflict: Questioning the assumptions of Osborn's brainstorming technique. The Journal of Problem Solving, 3(2), 5. http://dx.doi.org/10.7771/1932-6246.1093

Hines, P., \& Rich, N. (1997). The seven value stream mapping tools. International journal of operations \& production management, 17(1), 46-64. https://doi.org/10.1108/01443579710157989

Madzík, P. (2018). Increasing accuracy of the Kano model-a case study. Total Quality Management \& Business Excellence, 29(3-4), 387-409. https://doi.org/10.1080/14783363.2016.1194197

Maneechansook, C. (2011). Value Chain of Rice Exported from Thailand to Sweden (master's thesis). University of Borås. Borås.

Marques, C., \& Carvalho, M. (2017). A agricultura e os sistemas de produção da região Alentejo de Portugal: evolução, situação atual e perspetivas. Revista de Economia e Agronegócio, 15(3). Recovered from http://hdl.handle.net/10174/22004

Martínez Pérez, N. (2018). El apoyo al cultivo del arroz. Situación en el Lago de la Albufera (master's thesis). Universitat Politècnica de València. Valencia.

Melton, T. (2005). The benefits of lean manufacturing: what lean thinking has to offer the process industries. Chemical engineering research and design, 83(6), 662-673. https://doi.org/10.1205/cherd.04351

Morioka, S. N., \& Carvalho, M. M. (2016). Measuring sustainability in practice: exploring the inclusion of sustainability into corporate performance systems in Brazilian case studies. Journal of Cleaner Production, 136, 123-133. https://doi.org/10.1016/j.jclepro.2016.01.103

Ngamcharoenmongkol, P., Sen, S. K., \& Ongsakul, V. (2019). Sustainability intent transforming staple food in the Greater Mekong Sub-region: Qualitative study of Low Input and Niche Rice Value Chain. Journal of Business and Retail Management Research, 13(3). https://doi.org/10.1016/j.jclepro.2016.01.103

Nkuba, J., Ndunguru, A., Madulu, R., Lwezaura, D., Kajiru, G., Babu, A., \& Ley, G. (2016). Rice value chain analysis in Tanzania: identification of constraints, opportunities and upgrading strategies. African Crop Science Journal, 24(1), 73-87. https://doi.org/10.4314/acsj.v24i1.8S

Oka, H. I. (1988). Origin of cultivated rice. Tokyo. Elsevier. 
Research, Society and Development, v. 10, n. 7, e8310716224, 2021

(CC BY 4.0) | ISSN 2525-3409 | DOI: http://dx.doi.org/10.33448/rsd-v10i7.16224

Oliveira, J., Sá, J. C., \& Fernandes, A. (2017). Continuous improvement through" Lean Tools": An application in a mechanical company. Procedia Manufacturing, 13, 1082-1089. https://doi.org/10.1016/j.promfg.2017.09.139

Papademetriou, M. K. (2000). Rice production in the Asia-Pacific region: issues and perspectives. Bridging the rice yield gap in the Asia-Pacific region, 220. Recovered from http://www.fao.org/3/x6905e/x6905e.pdf\#page=9

Perilla, O. L. U., Gómez, A. G., Gómez, A. G., Díaz, C. Á., \& Cortezón, J. A. R. (2012). Methodology to assess sustainable management of water resources in coastal lagoons with agricultural uses: An application to the Albufera lagoon of Valencia (Eastern Spain). Ecological Indicators, 13(1), 129-143. https://doi.org/10.1016/j.ecolind.2011.05.019

Groos, O. V. \& Pritchard, A. (1969). Documents notes. Journal of Documentation, 25(4), 344-349. https://doi.org/10.1108/eb026482

Reig, E., Aznar, J., \& Estruch, V. (2010). A comparative analysis of the sustainability of rice cultivation technologies using the analytic network process. Spanish Journal of Agricultural Research, (2), 273-284. http://dx.doi.org/10.5424/sjar/2010082-1200

Sauerwein, E., Bailom, F., Matzler, K., \& Hinterhuber, H. H. (1996). The Kano model: How to delight your customers. In International Working Seminar on Production Economics, 1(4), 313-327.

Soebandrija, K. E. N. (2017). Green innovation and sustainable industrial systems within sustainability and company improvement perspective. In IOP Conference Series: Earth and Environmental Science, 109 (1), 12-30.

United Nations (UN) (2021). 17 Goals to transform our world. In Sustainable development goals. Recovered at 16/12/2020 at https://www.un.org/sustainabledevelopment/ 